\title{
Experiences by student nurses during clinical placement in psychiatric units in a hospital
}

\author{
WJC Van Rhyn, Ph.D., Senior lecturer, School of Nursing, UFS \\ MR Gontsana, M.Soc.Sc. (Nursing), School of Nursing, UFS
}

\section{Opsomming}

' $n$ Verkennende studie is onderneem met die doel om moontlike ervaringe wat deur psigiatriese verpleegkunde studente tydens kliniese plasing in 'n psigiatriese eenheid ondervind mag word, te ontdek en te beskryf.

'n Ongestruktureerde onderhoud is met elk van die deelnemers tydens hul eerste plasing in ' $n$ psigiatriese eenheid gevoer om die faktore wat hulle as stresvol beleef het, te identifiseer.

Die bevindinge het getoon dat al agt deelnemers gemiddelde tot hoë stres beleef het. Bronne van stres wat geidentifiseer is sluit, onder andere, die volgende in: oneffektiewe onderrig- en leerprogramme, swak bestuur van die diens, afsydigheid van professionele verpleegkundiges jeens hul onderrigrol, swak verhoudings onder personeel, te veel steun op die mediese model van versorging en verwaarlosing van pasiënte.

Die psigiatriese verpleegkunde studente wat by die studie betrek is het almal ondersteuning vir die volgende aangedui: indiensopleiding vir professionele verpleegkundiges, verandering van houding van professionele verpleegkundiges teenoor studente, ondersteuning vir student inisiatiewe, student betrokkenheid in pasiëntsorg en toereikende toewysing van hulpbronne vir pasiëntsorg en verpleegopleiding. Die verkenning en beskrywing van ervaringe wat deur psigiatriese verpleegkunde studente ondervind word sal verpleegopvoeders help om kliniese leergeleenthede op so "n manier te beplan dat dit minder stresvol sal wees. Dit sal verseker dat studente toegerus sal wees om hulself as terapeutiese instrumente te gebruik.

\section{Abstract}

An exploratory study was conducted with the aim of discovering and describing experiences of psychiatric nursing students during clinical placement in a psychiatric unit.

For the purpose of the study an unstructured interview was conducted with each participant during their first placement in a psychiatric unit to identify the factors experienced as stressful.

The results indicated that all eight participants experienced average to high stress. Sources of stress identified included, among others, ineffective teaching and learning programmes, poor managerial governance of the service, detachment of professional nurses from their teaching role, poor relationships among staff, overreliance on the medical model of care and patient neglect.

Psychiatric nursing students sampled indicated universal support for in-service education and training for professional nurses, attitude change of professional nurses towards students, support for student initiatives, student involvement in patient care and adequate allocation of resources for patient care and nurse training. The exploration and description of experiences of the psychiatric nursing students will help nurse educators plan clinical learning opportunities in such a way that they are less stressful, thus ensuring that psychiatric nursing students are equipped to utilise themselves as therapeutic instruments.

\section{Introduction and problem statement}

The system of nursing education has laid down extensive preparatory requirements for aspirant nurses in both the theoretical and practical components of their basic nursing education programs (Setsoe, 1992:32).
The acquisition of knowledge and experience in nursing specialities, used for selected learning experiences, allow these students to acquire increasing levels of skill in practice, and to emerge as expert nurses ready to provide a service of a comprehensive nature.

Research has identified nursing as a high stress profession. Nurses cope daily with extreme physical and psycho- 
logical demands inherent in providing care to acute and chronic populations. These demands of caring for others can be extremely stressful (Wheeler \& Riding, 1994:527).

Hlonipho (1994:2) noted that the experiences together with the major responsibility that students face while still undergoing training, for example learning unfamiliar and complex theory, as well as the practice of nursing, involving very ill and highly disturbed patients causes severe stress. Clinical experience is a basic component of the professional curriculum and serves as a unifying mechanism wherein concepts are rendered meaningful and principles tested.

Research acknowledging stress experienced specifically by student nurses has been extensively reported. The most common theme apparent throughout the literature on stress in the clinical experience, is that of students worrying about personal inadequacy and the possibility of making errors (Honipho, 1994:4; Kleehammer, Hart \& Keck, 1990:186).

Kleehammer et al. (1990:186) indicated further sources of anxiety to include procedures, inadequate hospital equipment, and interpersonal relationships with physicians and teaching staff members. They also reported that the highest level of anxiety expressed by students concerned the initial clinical experience. The stressful nature of this experience was also reported by Pagana (1988:419).

Thyer and Bazeley (1993:337) reported that the presence of stress can have implications for work performance, and could lead to mental ill health and psychomotor disorders. The authors also reported that students who experience unresolved stress and lack of emotional support are likely to experience impaired learning and performance ability.

Most of the studies on stress experienced in psychiatric settings focused on registered psychiatric nurses and psychiatrists (Gray \& Diers, 1992; Handy, 1991:44; Jones, Janman, Payne \& Rick, 1987:131). These groups of mental health professionals reported experiencing greater interpersonal involvement with their patients. This intimate contact and often intense relationship with disturbed people accounted for high levels of stress. They also reported that working in unresponsive, unappreciative and uncommunicative environments caused high stress.

Results from the above studies further indicate that psychiatric nurses are exposed to stressors common to other areas of nursing, for example staffing levels, overwork, administrative duties, to name but a few. In addition they face unique problems in their day to day work that reflect their interaction with a particular client group.

As Sullivan (1993:594) states, having to deal with patients who become physically violent, those that require continuous observation on a one-to-one basis because of their unpredictable behaviour and nursing a suicidal individual with a lack of manpower necessary to maintain a safe level, are unique problems of a nurse in a psychiatric setting.

It is reasonable to assume that student nurses working in mental health settings are as susceptible to stress as other mental health practitioners.

The literature indicates that there is a relationship between stress and learning. While some degree of stress is necessary to optimise learning, high levels of anxiety can impede learning and inhibit optimal functioning (Tyler \& Ellison, 1994:470)

It was found that when threat due to failure interacts with anxiety, interference with discrimination and abstraction is observed. Stress has a detrimental effect on skilled behaviour. This is pertinent in nursing education because discrimination, abstraction and skilled behaviour are necessary for safe, effective clinical practice.

Pagana (1988:418) noted that learning to be a nurse is stressful when she described it as "a perilous enterprise because it requires learning how to cope with many difficult and stressing situations ". It is possible then, that learning within these situations may be compromised due to the anxiety produced.

The stressors experienced by student nurses in the psychiatric units of the North West Province in South Africa have not been researched.

\section{Purpose and objective}

The purpose of the study was to explore and describe experiences by student nurses during their first clinical placement in psychiatric units. Nurse educators can then use the knowledge on stressors experienced by student nurses in the psychiatric clinical situation to plan clinical learning opportunities in such a way to make them less stressful, thus enhancing learning and practice skills of nursing students.

\section{Research design}

A qualitative study that was contextual, descriptive and exploratory was used with the objective of obtaining insight into the critical data required on the phenomenon being studied, and collecting accurate information.

The study was conducted in the psychiatric section of a hospital in the North West Province. This section is a 450bed institution serving a catchment area of a population of approximately 750,000 . It accommodates both chronic and acute mental patients. It is a teaching hospital for nursing programmes and it is the only institution in the area that offers psychiatric clinical experiences for nurses pursuing the integrated Diploma in Nursing (General, Community, Psychiatric Nursing) and Midwifery.

\section{Purpose and research objective}

This study focused on the experiences of student nurses during clinical placements in psychiatric units. The purpose of the study was to explore and describe experiences 
of student nurses during their first clinical placement in psychiatric units. Nurse educators can then use the knowledge on experiences by student nurses in the psychiatric clinical situation to plan clinical learning opportunities in such away to make them less stressful, thus enhancing learning and practice skills of nursing students.

\section{Terminology}

\section{Psychiatric Nursing Student}

A learner acquiring knowledge and skill in the practice of psychiatric nursing during the third year of training.

\section{Psychiatric Unit}

A setting in which psychiatric nursing students receive clinical experience with hospitilised mentally ill patients.

\section{Experiences}

Events or circumstances experienced by psychiatric nursing students in the psychiatric setting as stress producing.

\section{Research design}

A qualitative study that was contextual, descriptive and exploratory was used with the objective of obtaining insight into the critical data required on the phenomenon being studied, and collecting accurate information.

The study was conducted in the psychiatric section of a hospital in the North West Province. This section is a 450bed institution serving a catchment area of a population of approximately 750,000 . It accommodates both chronic and acute mental patients. It is a teaching hospital for nursing programmes and it is the only institution in the area that offers psychiatric clinical experiences for nurses pursuing the integrated Diploma in Nursing (General, Community, Psychiatric Nursing) and Midwifery

The study population comprised of third year full-time psychiatric nursing students pursuing the integrated Diploma in Nursing (General, Community, Psychiatric Nursing) and Midwifery. Students following an integrated programme are placed in psychiatric wards for the first time in their third year. A purposive convenience sample of nursing students who voluntarily agreed to participate in the study was selected. A sample of eight nursing students was drawn. The sample size was depended on saturation of data when no more new data was collected.

Nursing students included in the study were:

- those in the third year of the program in a nursing college

- those in the above level of study, assigned for the first time to provide care to psychiatrically ill patients in the psychiatric section of Bophelong Community Hospital

- $\quad$ both male and female students

A pilot study with two participants from the fourth year of study senior to the proposed sample group was conducted to identify possible problems in gathering data.

To identify the information concerning stressors experienced by the participants in the clinical situation an indepth unstructured interview was conducted. Two questions were asked:

- Describe the factors which cause you stress while working in a psychiatric unit

- What would you recommend to reduce your stress and improve your placement in a psychiatric unit?

Each interview session was tape-recorded and transcribed. Notes were also taken during data gathering.

For the purpose of the study Guba's model for establishing trustworthiness of qualitative research was used (Krefting 1991: 215). The model is based on four aspects: truth value, applicability, consistency and neutrality. Strategies applied to ensure trustworthiness were:

Credibility: The researcher is a registered nurse with ten years experience as a tutor. Interviews were conducted on different days and times with different participants. Field notes were taken. An independent co-coder was used. The research was conducted under the supervision of an experienced qualitative researcher (with doctoral degree in nursing).

Transferability: A purposive convenience sample was used. A complete description of the methodology including literature control and verbatim quotes from individual interviews were included.

Dependability: Question checking with literature was done. Tesch's steps of data analysis were followed (CresweI 1 1994: 155). Consensus discussion between researcher and cocoder was done.

\section{Results}

The data was saturated after eight participants had been interviewed, necessitating no further interviews.

A systematic process of analysing data as described by Tesch and quoted by Creswell (1994: I55) was used to ensure uniformity in the analysis of the interviews. Themes, categories and sub-categories were identified from the experiences described by the participants. An independant co-coder with experience in qualitative research (with doctoral degree) was used.

In analysing the data gathered from the participants, the major themes identified were lack of integrating theory with practice, failure of the service to appreciate a holistic approach to psychiatric care, lack of professional support and lack of resources (see Table 1). These themes will be discussed and substantiated by the appropriate quotes from the transcripts and literature.

\section{Lack of integration of theory with practice}

The findings indicate the existence of two categories in 
Table 1: Major themes, categories and sub-categories

\begin{tabular}{|c|c|c|}
\hline MAJORTHEME & CATIYGORY & SUB-CATEGORIFS \\
\hline \multirow[t]{2}{*}{$\begin{array}{l}\text { 1. Lack of integration of } \\
\text { theory to practice }\end{array}$} & $\begin{array}{l}\text { Ineffective teaching and learning pro- } \\
\text { grammes for psychiatric nursing stu- } \\
\text { dents }\end{array}$ & $\begin{array}{l}\text { - No correlation between theory and } \\
\text { practice } \\
\text { - No proper orientation of participants } \\
\text { to the clinical situation } \\
\text { - Unclear/absence of clinical learning } \\
\text { objectives } \\
\text { - Limited exposure to the clinical units } \\
\text { - Overcrowding of students in the clini- } \\
\text { cal situation }\end{array}$ \\
\hline & De-motivated students & $\begin{array}{l}\text { - Lack of interest in psychiatric nurs- } \\
\text { ing } \\
\text { - Feeling emotionally drained } \\
\text { - Lack of potential/inadequacy of par- } \\
\text { ticipants in giving care to psychiatric } \\
\text { patients } \\
\text { - Fear of psychiatric patients }\end{array}$ \\
\hline \multirow[t]{2}{*}{$\begin{array}{l}\text { 2. Failure of the service to } \\
\text { appreciated a holistic approach } \\
\text { to psychiatric nurse care }\end{array}$} & $\begin{array}{l}\text { Over-reliance of the service on the medi- } \\
\text { cal model of care }\end{array}$ & $\begin{array}{l}\text { - Failure to use other methods of treat- } \\
\text { ment } \\
\text { - Lack of rehabilitation programmes for } \\
\text { patient care }\end{array}$ \\
\hline & $\begin{array}{l}\text { Failure to provide a therapeutic environ- } \\
\text { ment }\end{array}$ & $\begin{array}{l}\text { - Use of de-humanising equipment for } \\
\text { psychiatric care } \\
\text { - Unkept ward environment } \\
\text { - Working environment not conducive } \\
\text { to patient care }\end{array}$ \\
\hline \multirow[t]{3}{*}{$\begin{array}{l}\text { 3. Inadequate/insufficient } \\
\text { professional support }\end{array}$} & $\begin{array}{l}\text { Poor managerial governance of the serv- } \\
\text { ice }\end{array}$ & $\begin{array}{l}\text { - Failure by the participating college } \\
\text { to place students in an adequate train- } \\
\text { ing facility } \\
\text { - Resisting students inputs into the } \\
\text { management process } \\
\text { - Understaffing of registered psychi- } \\
\text { atric nurses in psychiatric units } \\
\text { - Absence of the multidisciplinary team }\end{array}$ \\
\hline & $\begin{array}{l}\text { Detachment of the professional nurses } \\
\text { from their teaching role }\end{array}$ & $\begin{array}{l}\text { - Inadequate knowledge of the sub- } \\
\text { ject } \\
\text { - Lack of professional commitment }\end{array}$ \\
\hline & $\begin{array}{l}\text { Poor relationships among staff, manage- } \\
\text { ment staff and participants }\end{array}$ & $\begin{array}{l}\text { - Inadequate communication among } \\
\text { staff, management and the participants }\end{array}$ \\
\hline 4. Lack of resources & Patient neglect & $\begin{array}{l}\text { Misuse of sub-professional catego- } \\
\text { ries of nursing to do the duties of pro- } \\
\text { fessional nurse } \\
\text { - Use of patients as workforce }\end{array}$ \\
\hline
\end{tabular}


this major theme, namely, ineffective teaching and learning programmes for psychiatric nursing students and de-motivated nursing students.

Greaves (1985:40) views integration as a way of organising the curriculum to assist the learner to analyse and apply the relationship between content, concepts and principles in their practice. A nurse must be able to put into practice what she has learnt in theory, apply the knowledge obtained in classroom situations, exercise educated judgement and make skilled observations throughout the process of caring for a patient.

To be able to do all this she needs practice skills and information. Skills and information are learnt in an interactive manner. It is impossible to learn one without the other in practice professions such as nursing.

\section{Ineffective teaching and learning programme for psychiatric nursing students}

Five sub-categories were identified under this category namely, no correlation of theory to practice, no proper orientation of participants to the clinical situation, unclear/ absence of clinical learning objectives, limited exposure to the clinical units, and overcrowding of students in clinical units.

Almost all eight participants described in some way the problem of applying facts learned from a book or in the classroom to the day-to- day nursing care as very distressing. They reported being unable to understand and correlate what they saw in the wards with what they were taught, and the following excerpt from their interviews characterise this sub-category:

"you are in the theoretical setting doing schizophrenia and when you go to the clinical area you are allocated to a mentally retarded ward."

The participants of the study used words such as merge, link, apply, to describe this lack of co-ordination.

Half (50\%) of the participants reported a feeling of lost and not welcome in the units. The quotation below supports these feelings:

"... in fact we did not know what was expected of us. The orientation we were given did not help us in any way ... we were lost in those units ... we needed to be supported now and again and this was not forthcoming."

Pohl (1978:87) stated that orientation of new workers to the nursing unit is an important process, not only for the effective functioning of the unit but also for the personal adjustment and work satisfaction of the new person.

The present findings are in agreement with Hlonipho (1994:6) who reported that it is a frightening experience for students to be expected to work in the clinical setting before they are orientated irrespective of their level of training. She further stated that $80 \%$ of the students experienced high levels of stress when they were not properly orientated, shown procedures and given the necessary supportive guidance.

Four of the participants reported that they were unaware of what was expected of them. What were they to accomplish in the patient units in view of the fact that nothing was planned for them? The statements below made by participants bear testimony to this:

"they do not know why we are in those units ...no objectives."

"when I get into the psychiatric ward, I need to he aware of what the ward objective are, and at the same time, what the psychiatric ward sister expect of me ...clear description of these will be helpful to us as student, because we will be focused."

Available literature emphasises that carefully formulated objectives give both the nurse and the student direction for planning, carrying out and evaluating education (Greaves, 1985:79; Mellish \& Brink, 1989:252).

Two of the participants reported being exposed to the psychiatric unit for very short periods. Two weeks, a month and/or three weeks were cited as placement periods, and this was reported as making learning and caring for patients difficult.

This is how they substantiated the notion:

"The hours allocated for psychiatric nursing practise are very short, sometimes you are allocated for two weeks and you cannot do what you wanted to do. ... like you want to implement a rehabilitation programme for the patient. It means you work only the first week to establish a working relationship you cannot do all that you wanted to do for the patient."

"This is our second exposure to the psychiatric clinical units ... I can say this is the third week because last time it was only two weeks and I really gained nothing."

This finding is supported by Mokoena (1991:6) who reported that the preparation of a nursing student into the role of a professional nurse in the work environment was inadequate due to insufficient time allocated for practical work and experience.

Five of the participants reported being allocated in large numbers in one unit and related this to their inability to learn because of insufficient learning opportunities, as expressed in the statement below:

"About eight or nine students are allocated to a single ward which can actually accommodate four to five students, and as a result the unit is in itself no longer an educative situation, ... We are all there doing nothing, we are actually overcrowded as students."

This finding corroborates those of other researches. 
Bestenbier (1992:99), in her study of stress experienced by nursing students during psychiatric clinical practica stated that too many students at various institutions were allocated to the same wards at the same time.

\section{- De-motivated students}

Four sub-categories were identified namely, lack, of interest in psychiatric nursing, feeling emotionally drained lack of potential or inadequacy in giving care to psychiatric patients and fear of psychiatric patients.

Participants reported being de-motivated and frustrated about being in the psychiatric unit. Newstrom and Davis (1997:37) stated that, frustration is a result of a motivation (drive) being blocked to prevent one from reaching a desired goal. This situation becomes more serious when there is long-run frustration.

The participants of this study expressed their long-standing frustration through concepts such as not interested, bored and discouraged. The experiences of the participants are presented below.

Five participants reported feeling discouraged, having diminished interest and being miserable because of the negative attitudes of other staff and the environment they were working in, the statement from their transcripts illustrate this:

"The nurses ignore you and you end up hating the situation and seeing these nurses as not interested in your welfare as a student."

In a few instances participants quoted incidents in which they were passive observers rather than real participants in the situation. They identified a variety of unit problems that contributed to their low morale, for instance, resistance of staff especially assistant nurses, to new ideas, feelings of neglect by the hospital and the college and having no leaders, except for temporary leaders. This led to their withdrawal from both the patients and the staff.

Schwartz and Will as quoted by Gray and Diers (1992:27), defined "mutual withdrawal" (possibly observed in the present study) as a coping mechanism used by nurses to deal with low morale. The withdrawal of nurses from patients and from each other occurred in a cycle: nurses expected support from other staff, but did not receive any, and patients expected staff support, but received none. Both responded by withdrawing.

Two participants reported feeling tired, tense and exhausted" The work stressors that emerged as contributing most to feelings of emotional exhaustion related to the varied and complex nature and treatment of mental health problems as reflected in the statement below:

"end up tired the whole day, and at home you are tired."

Maslash as cited by Basson and van der Merwe (1992:21) asserts that younger and less experienced workers are more prone to emotional exhaustion than more experienced workers. The above may be seen by participants as relatively unimportant, but when seen in the light of the developmental needs of the student nurses it takes on a different complexion. Environmental effects such as rigid ward routines and physical feelings of stress such as exhaustion, accounted for a number of stressors.

Issues of responsibility and fears of giving inadequate care to patients, are a major source of concern among qualified nurses (Parkes, 1985:948). Similar concerns were apparent in the present study. The psychiatric nursing students' vulnerability and inexperience, combined with the situational demands, were the major factors underlying feelings of inadequacy in this study.

Almost all eight participants reported feeling inadequate in giving care to patients. The comment below reflects this notion.

“... their behaviour will start to change and you start pulling out of the situation, you need somebody, you cannot handle this by your."

Two participants identified fear of psychiatric patients as a problem. Experiences were stated in a subtle manner as indicated in the statement below:

"Other patients are difficult to manage especially if you are a student. They tend to bully us ... and it will be like you are afraid of the patient, you cannot do anything for the patient ..."

The finding corresponds with that of Pagana (1989:402). The comments reflective of uncertainty in her study mainly refer to fear of the unknown and uncertainty regarding expectations. Warner (1991:12) reported that students who observed bizarre behaviour in patients expressed their tension as surprise, fear, suspicion and embarrassment. The patient behaviours that violated the social norms made students feel tense and uncomfortable.

\section{Failure of the service to appreciate a holistic approach to psychiatric nursing care}

Two categories were identified from this major theme, namely: over- reliance of the service on the medical model of care, and failure to provide a therapeutic environment for patients.

\section{- Over-reliance of the service on the medical model of care}

Over-reliance of the service on the medical model of care was a problem. Proponents of the medical model view emotional and behavioural disturbances in the same way as they view physical disease. They focus on the diagnosis of a mental illness and subsequent treatment is based on this diagnosis with somatic treatments being the important components of the treatment process. The interpersonal aspect of the medical model varies widely, from intensive 
insight oriented intervention to brief, superficial medication supervision. This view has implications for psychiatric nursing practice, because when nurses care for psychiatric patients they are primarily responsible for their wellbeing.

Providing nursing care is a collaborative effort, with both the nurse and the patient contributing ideas and energy to the therapeutic process.

Five participants reported that patients were given only medication as a form of treatment and they claim this made it difficult to interact with patients because they remained drowsy for most of the day.

The statement made by the participants bear testimony to this:

"you have to use resources in the clinical situation ward for the good of the patient, but because of the effects of medication, you cannot use them."

Beck, Rawlins and Williams (1988:21), states that the holistic health principles of practice constitute a framework that can be used in any care setting, and that it enhance quality care.

One of the fundamental roles of the nurse is to enable people with mental health problems to meet their basic needs and to restore the individual's well-being as far as possible, and this she can do by adopting holistic health principles of practice.

Almost all participants reported that recreational facilities were not adequate for patient care. They stated that patients were idling for most of their stay, their statements clearly emphasise this aspect.

"what we do is to stay with the patients in the ward, for the whole day, or could actually take them to the sport ground which is no more there, because it is used as an area where contractors are working ... so we just have to stay for the whole day Monday to Monday."

"you are not only short of facilities for occupying patients, they themselves are in tatters."

\section{- Failure to provide a therapeutic environment}

Beck et al. (1988:461) refers to a therapeutic environment as the general setting where treatment occurs regardless of the philosophy of treatment. Nursing assumes an important function in the creation of a therapeutic environment in that the nurse provides for healthy interactions and learning situations that enable the patient adequate adjustment. Privacy, safety, protection and comfort are components of a therapeutic environment.

According to the participants' statements, patients in this study were not afforded these components.
Of the eight participants, six felt strongly that the use of equipment was not therapeutic for the care of psychiatric patients, they reported that patients were devalued, and this is how they expressed it:

"If you can see the dishes they are eating with, the cups they are drinking from ..., are not psychiatrically therapeutic."

"eating from dishes that are demeaning ..., not really or human use."

One of the participants reported that the physical work environment was not well kept. Wards were described as dirty. Words like fil thy and unkept were used. The quotation below captured this experience:

"Psychiatric units themselves are usually' very filthy ..., they are not clean ... and because of the conditions prevailing there, they are now very dirty and there is nobody who enjoys to stay in such conditions for the whole day."

The finding coincides with Dawkin, Depp and Selzer (1986:11). The authors identified aspects such as lack of cleanliness and maintenance and noise within the environment as distressing.

All the participants reported that the environment was not conducive to patient care" It provided no privacy, protection and/or security to patients" The participants' concerns are reflected in their statements:

"The environment within the wards is not pleasing, patients move around without clothes and there are no fences, so patients' security is not guaranteed. It is like nobody cares."

\section{Inadequate / insufficient professional support}

Three categories were identified, namely poor managerial governance of the service, detachment of the professional nurses from their teaching role, poor relationships among staff, management and participants.

\section{- Poor managerial governance of the service}

Four sub-categories, namely failure of the participating college to place students in an adequate training facility, resisting students inputs into the managerial process, understaffing of registered psychiatric nurses in psychiatric units and absence of the multidisciplinary team members.

Issues referred to in this category related to organisational practices. Stress centred around practices that indicated valuing of the service over clients and staff, and an uncommunicative work environment that makes changes for the sake of changes.

Services of the participating hospital were in such a state 
that both patient care and nurse training were threatened. Participants were placed for clinical experiences even though conditions were not favourable, as this was the only psychiatric hospital in the province. Participants do felt cheated and that their learning needs were not taken seriously.

Five of the participants identified this sub-category as stressful and their experiences are captured in the statement that follows:

"I think if you place students where administration is generally poor, you are exposing those students to an area that is very critical, which is going to act negatively to their academic development or their mental development as students."

The development of a student nurse involves both professional development and personal development, and both are facilitated in the learning process. Involvement of students in decision-making is necessary for the functioning of the college. Even though the participants of this study were involved at decision-making level, they felt their inputs were never accepted and this caused stress for them.

Two of the participants felt strongly about this sub-category. A comment is reflected in the statement below:

"Because of the background of where we come from, there is this tendency..., that we have to be passive consumers of information. We don't have to make inputs to the authorities because I think they believe that they cannot have ideas from people who are supposed to he taught."

All eight participants reported that there were understaffing of registered psychiatric nurses in psychiatric units and that this led to insufficient and/or inappropriate guidance in these areas. The statements below bear testimony to this view:

"The wards are most of the time without registered nurse, the bulk of the personnel allocated to these wards are assistant nurses and a few enrolled nurse ... there are no registered psychiatric nurses. This affects our training, ... because when the sister is off-duty or is not there, there is no one who guides us."

Six participants reported that the multidisciplinary team approach is not practised in this institution because of lack of team members. The statement from their transcript emphasise this concern:

"There is no psychiatrist ... and some of the patients ... according to our own evaluation can go home, but without the psychiatrist's assessment ... they remain long in the hospital and finally develop institutional neurosis."

\section{- Detachment of the professional nurses from their teaching role}

When students join the nursing profession, it is assumed that they know nothing or at the most, little about nursing.
They must be guided to a stage where they can assume responsibility for their nursing actions. This socialisation process has traditionally been and is still the function of professional nurses.

Seven participants reported that the professional' nurses could not impart knowledge and showed minimal interest in the whole process of student learning. Some of their inputs are captured in the statement that follows:

\section{"When you request their guidance they refer you to the} nurse educators."

All eight participants reported that both the ward sisters and the clinical tutors had no interest in their work. The excerpts below summarise this aspect:

"In most instances even the presence of a registered nurse does not help you ... they are most of the time visiting other sisters in other wards. If they are in the ward they are at the nurses station and only giving directives."

"At times the psychiatric nurse is there, but the attitude of the psychiatric nurse is not conducive for him and for the student to interact."

In a few comments participants expressed the desire for clinical tutors to be more supportive and to spend more time with them. One participant said:

"As students we are expected to be continually assessed but the clinical tutors do not make themselves available in guiding us, you know ... thus it becomes difficult because we meet at a specific time, and for the rest of the time you don't integrate with them."

\section{- Poor relationships among staff, management and participants}

Problems reported by the participants included ineffective/ inadequate interaction and communication that not only affected students but was also noticeable between nurse educators and ward sisters, and between ward sisters and management. One sub-category was identified.

Interpersonal problems between juniors and those in charge, are widely regarded as sources of stress in hospital settings (Parkes, 1985:947). In the present study many of the interpersonal problems reported were due to attitude problems. Experiences below capture this:

"The nurses on the other hand are not friendly, their interpersonal relationship is not good and this obstructs you as a student from asking questions."

\footnotetext{
"Being treated like ordinary workers" was also a frequent and understandable source of resentment, since the majority of these participants were striving to achieve a professional status and independence.
}

Working relationships between staff members were also a 
potential source of problems. Participants expressed concern at the attitude of the ward sisters to nurse educators, and this they said occurred sufficiently frequent to have a lasting and adverse effect on their motivation, as captured in the following experience of a participant:

“... the students may not e... are not that much interested and even the psychiatric nurses working in there, does not interrelate rightly to the tutors, to the extent that they can hardly transfer what the tutor told them to transfer to us, as it is ..."

Parkes (1985:947) made a similar finding. He pointed out that the tendency for ward sisters to reprimand students who had made mistakes, rather than to respond to their needs and the distress this caused for students. The subjects in the perceived themselves as powerless to argue even if they were blamed unjustly.

\section{Lack of resources}

The findings indicated one category in this major theme, namely, patient neglect.

\section{- Patient neglect}

Students were concerned about non-professional nurses taking charge in psychiatric units and patients being misused.

Almost all participants reported concern at the free use of both assistant nurses and enrolled nurses as charge nurses in the psychiatric units. Their statements bear testimony to this:

"A psychiatric ward is run by enrolled nurse ... she is just using her experience, but she is actually not qualified ..., she uses more of the practical part of it, which is not according to theory."

"... these nurses at times give patient over-dosage because they do not know anything about psychiatric care."

Participants of the present study felt they were not gaining anything from the psychiatric hospital because they were supervised and taught by this enrolled category.

Four participants reported that patients were abused by using them to do duties for which personnel were hired. Patients were cleaning other patients, feeding those who were unable to feed themselves and cleaned the units. The participants reported this as follows:

"Patients are used as workforce to clean the wards even though cleaners are hired and are paid."

One participant stated that it was demoralising to observe the treatment offered to patients. He had this to say:

"Patients are really not cared for. As a student you always ask yourself how you will feel if it was brother or father being treated this way the way they are treated increases the stigma attached to them."

\section{Conclusion}

The present study aimed at identifying factors that cause stress in psychiatric nursing students.

The main theme that evolved from the content analysis was that participants' stress was increased by what they experienced as non-supportive staff in the clinical situation. This finding is supported by those of Pagana (1985:422) and Kleehammer et al. (1990:187). The concurrence of findings is an indication that clinical staff needs to be continually cognisant of how their interactions with students are perceived. Clinical nursing personnel seen to be non-supportive may have a great negative impact on the student's ability to learn due to stress.

The non-stimulating, non-supportive environment in which the participants found themselves, affected them so seriously that they were not interested and had no potential for giving patient care.

Relevant knowledge and skills are largely inevitable in the early stages of training, but the initial placement in the clinical situation, (as in the case of these students) can be exciting and challenging if careful teaching and supervision are provided.

Ward sisters and senior nurses are charged with this function. But one must not lose sight of the fact that ward sisters themselves are under considerable stress and they see patient care, rather than teaching students as their first priority. This was also indicated in the responses of participants, who stated that they were referred to the tutors when they requested assistance from sisters. A further reason for their reluctance to teach may be the lack of the skills necessary to carry out these two conflicting aspects of their role.

A generally negative conception of management was noted in the study and this deserves some explanation. The finding suggests that the psychological conditions in which psychiatric nursing students work may be problematic. The students in the current study held strong views about the organisational characteristics of the research setting and believe that their views were not taken into consideration when important decisions were taken.

The results could indicate the reality of the situation or alternatively, they could reflect some underlying feeling of discontent manifesting in this manner. As Trygstad (1986:25) noted, discontent amongst nurses is a comment on the style of leadership, patterns of communication and quality of interactions that operate within the work environment. Ultimately an individual's experience of stress occurs within an organisational context and the contextual variables in operation will affect the appraisal of stress by the individual.

The psychiatric clinical setting of this study was part of a particular set of organizational relationships. Being part of 
the National Health Service facilities, all interactions took place within a specific social climate which was characterised by uncertainty.

The economic situation and changes in the political philosophy have produced a culture characterised by reduced financial provision for health care accompanied by an increasing demand for these services. The organisation of care within these services is therefore a reflection of a particular structure, and various policies and procedures in operation impose various constraints. While some sources of stress are the result of the clinical work of nurses, others reflect a specific organisational context.

\section{References}

BASSON, CJ \& VAN DER MERWE, I 1994. Occupational stress and coping in a sample of student nurses. Curationis. 17(4):35-43.

BECK, CK; RAWLINS, RP \& WIL LIAMS,SR 1988. Mental health-psychiatric nursing- a holistic life-cycle approach, $2^{\text {nd }}$ ed. St Louis: C. V. Mosby.

BESTENBIER, MC 1992. Experience of stress by nursing students during psychiatric nursing clinical practice. Johannesburg: Rand Afrikaanse Universiteit (unpublished).

CRESWELL, J 1994. Research design, qualitative and quantitative approaches. California: Sage publishing

DAWKINS, JE; DEPP, FC \& SEIZER, NE 1986. Stress and the psychiatric nurse. Journal of Psychosocial Nursing, 23(11):9-15

GRAY, S \& DIERS, D 1992. The effects of staff stress on patient behaviour. Archives of Psvchiatric Nursing. 6( 1):26 -34 .

GRFAVES, E 1984. Nurse education and the curriculum. A curricular model. London: Chroom Helm.

HANDY, J 1991. Stress and contradiction in psychiatric nursing. Human Relations, 44(1):39-53.

HI.ONIPHO, MM 1994. Stress experienced by student nurses in the clinical area. Department of Nursing, University of Bophuthatswana (unpublished).

JONES, JG; JANMAN, K; PAYNE, RL \& RICK, JT 1987. Some detenninants of stress in psychiatric nurses. International Journal of Nursing studies, 24(2): 129-144.

KLEEHAMMER, K; HART, L \& KECK, JF 199(). Nursing students perceptions of anxiety producing situations in the clinical setting. Journal of Nursing Education. 29(4): 183 187.

KREFING, $L$ 1991. Rigor in qualitative research: An assessment of trustworthiness. The American Journal of Occupational Therapy. 45(5):214-222.
MELLISH, JM \& BRINK, H 1989. Teaching the practice of nursing. $2^{\text {nd }}$ ed. Butterworths: Durban

MOKOENA. BA 1991. Professional socialisation as a curriculum component for training of nursing students at the University of Bophuthatswana (unpublished).

NEWSTROM, W \& IDAVIS, K 1997. Organisational behaviour. Human behaviour at work. $10^{\text {th }}$ ed. New York: McGraw-Hill Companies, Inc.

PAGANA, KD 1988. Stresses and threats reported by Baccalaureate students in relation to an initial clinical experience. Journal of Nursing Education. 27(9):418-424.

PARKES, KR 1985. Stressful episodes reported by firstyear student nurses: A descriptive account. Journal of Social Science and Medicine. 20(9):945-953.

POHL, M 1978. The teaching function of the nursing practitioner. $3^{\text {rd }}$ ed. Dubuque: W.M.C. Brown Company Publishers.

SE'TSOE, G 1992. Selection of student nurses at Bafokeng Nursing College. Curationis. 15(2):31-35.

SULLIVAN, PJ 1993. Occupational stress in psychiatric nursing. Journal of Advanced Nursing. 18:591-601.

THYER, SE \& BAZELEY, P 1993. Stressors of student nurses beginning tertiary education - An Australian study. Nurse Education. 13:336-342.

TRYGSTAD, LN 1986. Stress and coping in psychiatric nursing. Journal of Psvchosocial Nursing. 24 (10):23-27.

TYLER, PA \& ELLISON, RN 1994. Sources of stress and psychological wellbeing in high-dependency nursing. Journal of Advanced Nursing. 19:469-476.

WARNER, SL 1991. A coping response for student nurses. Archives of Psuchiatric Nursing. 5(1):10-16.

WHEELER H \& RIDING, R 1994. Occupational stress in general nurses and midwives. British Journal of Nursing. $3(10): 527-534$ 